\title{
Burnout Syndrome and the Work Design of Education and Health Care Professionals
}

\author{
Mary Sandra Carlotto ${ }^{1}$ \\ Gardênia da Silva Abbad² \\ Marina Greghi Sticca ${ }^{3}$ \\ Maria Nivalda de Carvalho-Freitas ${ }^{4}$ \\ Marcos Santos de Oliveira ${ }^{4}$ \\ ${ }^{1}$ Universidade do Vale do Rio dos Sinos, São Leopoldo, Rio Grande do Sul, Brasil \\ ${ }^{2}$ Universidade de Brasilia, Brasilia, Distrito Federal, Brasil \\ ${ }^{3}$ Universidade de São Paulo, Ribeirão Preto, São Paulo, Brasil \\ ${ }^{4}$ Universidade Federal de São João del-Rei, São Joal del Rei, Minas Gerais, Brasil
}

\begin{abstract}
This study aimed to identify the predictive power of the Work Design (WD) variables on Burnout Syndrome (BS). The sample consisted of 300 professionals, 188 from the field of education and 112 from health care. Two instruments were used in this research, a reduced version of the Work Design Questionnaire (WDQ) and the Brazilian version of the Spanish Burnout Syndrome Inventory (SBI). The results showed that in both professional categories, the factors of work design are predictors of the 4 dimensions of BS, especially factors related to social and task characteristics. In the education field, characteristics of knowledge required by work appear as predictors of only psychological exhaustion; and in health care professionals, as predictors of psychological exhaustion and decreased Enthusiasm towards the job. Implications of these findings will be discussed in terms of their applicability in interventions to prevent BS based on work redesign actions.

Keywords: occupational stress; work; education professionals; health professionals.
\end{abstract}

Síndrome de Burnout e o Desenho do Trabalho de Profissionais da Educação e Saúde

\begin{abstract}
Resumo
Este estudo buscou identificar o poder preditivo de variáveis do Desenho do Trabalho (DT) sobre a Síndrome de Burnout (SB). A amostra foi constituída por 188 profissionais da educação e 112 da saúde. Dois instrumentos foram utilizados nesta pesquisa: uma versão reduzida do Questionário de Desenho do Trabalho (QDT) e a versão brasileira do Cuestionario para la Evaluación del Sindrome de Quemarse por el Trabajo (CESQT). Os resultados mostraram que em ambas as categorias profissionais os fatores de desenho do trabalho, especialmente as características sociais e das tarefas, são preditores das quatro dimensões da SB. Na educação, características do conhecimento requerido pelo trabalho aparecem como preditoras apenas do desgaste psíquico; e na saúde, como preditoras do desgaste psíquico e da diminuição da ilusão pelo trabalho. Implicações desses achados serão discutidas em termos de sua aplicabilidade em intervenções para prevenir a SB a partir de ações de redesenho do trabalho.

Palavras-chave: stress ocupacional, trabalho, pessoal de educação, pessoal da saúde
\end{abstract}

Síndrome de Burnout y el Diseño del Trabajo de Profesionales de la Educación y de la Salud

\begin{abstract}
Resumen
Este estudio buscó identificar el poder predictivo de las variables de Diseño del Trabajo (DT) en el Síndrome de Burnout (SB). La muestra estuvo conformada por 300 profesionales, siendo 188 del ámbito educativo y 112 del sanitario. Se utilizaron dos instrumentos en esta investigación, una versión reducida del Cuestionario de Diseño del Trabajo (QDT) y la versión brasileña del "Cuestionario para la Evaluación del Síndrome de Quemarse por el Trabajo" (CESQT). Los resultados indicaron que, en ambas categorías profesionales, los factores de diseño del trabajo son predictores de las cuatro dimensiones de la SB, especialmente los factores relacionados con las características sociales y de la tarea. En la educación, las características de los conocimientos requeridos para el trabajo solo aparecen como predictores del desgaste psíquico; y en el campo de la salud, como predictores del desgaste psíquico y de la disminución del entusiasmo por el trabajo. Las implicaciones de estos hallazgos serán discutidas en términos de su aplicabilidad en intervenciones para prevenir la SB a partir de acciones de rediseño del trabajo.

Palabras clave: estrés laboral; trabajo; profesionales de la educación; profesionales de la salud.
\end{abstract}

Burnout Syndrome (BS) has been defined as a consequence of chronic work stress and constitutes a subjective negative experience composed of cognitions, emotions and negative attitudes towards work
(Gil-Monte, 2011). In the model proposed by GilMonte (2005), the syndrome consists of 4 dimensions: 1) Enthusiasm towards the job (evaluated in an inverse way to characterize BS), which indicates one's desire to 
achieve work-related goals, perceived by the individual as attractive and a source of personal fulfillment; 2) Psychological Exhaustion, characterized by the feeling of emotional and physical exhaustion in relation to direct contact with people who have or cause some kind of problem; 3) Indolence, evidenced by the presence of indifference towards people who need to be cared for in the work environment, as well as insensitivity to the problems of others; 4) Guilt, characterized by the feeling of guilt about the negative behavior and attitudes developed at work that do not correspond to the internal rules and social demands of the professional role.

Currently, BS is one of the most investigated themes in Occupational Health Psychology due to the results of research that have confirmed its serious implications for the health of workers and organizations (Bakker \& Costa, 2014), generating important social and economic costs (Maslach, 2017). BS is already recognized as an occupational disease in several countries, such as the Netherlands, Sweden, Venezuela, Colombia, and Brazil (Chirico, 2017). It is an occupational risk that affects professionals involved in any type of care in a relationship of continuous and intense level of personal and emotional contact, with emphasis on health care and education services (Maslach \& Leiter, 2016b).

The literature has confirmed over the years the role of variables related to the perception of the worker, such as workload (Galindo et al., 2012; Lima et al., 2013; Novais et al., 2016; Rodrigues \& Carlotto, 2017; Silva et al., 2015; Tironi et al., 2016), organizational support (Lorenz \& Guirardello, 2014), autonomy (Rodriguez \& Carlotto, 2017), recognition at work (Prestes et al., 2015; Zanatta \& Lucca, 2015), and working conditions (Silva, Bolsoni-Silva, Rodrigues, \& Capellini, 2015) in the prediction of BS. Although certain socio-demographic and individual variables such as sex (Carlotto, 2011), age (Esteves-Ferreira, Santos \& Rigolon, 2014; Koga, et al., 2015), and marital status (Zanatta \& Lucca, 2015), among others, have indicated a relation to BS in the explanatory models, they generally have low predictive power, (Maslach, Schaufeli, \& Leiter, 2001; Queirós, Carlotto, Kaiseler, Dias, \& Pereira, 2013; Sticca \& Scotton, 2019) when compared to work-related variables, which points to the importance of the design and characteristic of the work context as determinants of the occurrence of BS (Maslach \& Leiter, 2016 a).

Among the group called work-related variables, several studies over the years have been dedicated to analyzing the relationship between work design and
BS (Borritz et al., 2005; Fernet, Austin, Trépanier \& Dussault, 2013; Jindal, Garg, \& Rastogi 2014; Pisanti et al., 2016). Morgeson and Humphrey (2006) defined work design as the study, creation, and modification of the composition, content, structure, and environment in which tasks and roles are performed, and proposed a model composed of 4 dimensions: characteristics of the task, characteristics of knowledge, social characteristics, and characteristics of the context. The instrument, composed of 77 items and submitted to confirmatory factor analysis, indicated the presence of 5 multifactorial empirical structures (with 4, 18, 19, 20 and 21 factors), but the factorial solution that obtained more evidence of validity in the study by Morgeson and Humphrey (2006) was that of 21 factors. This questionnaire was translated and adapted into Portuguese by Borges-Andrade, Peixoto, Queiroga, and Perez-Nébra (2019). The Brazilian version, submitted to exploratory and confirmatory factor analyses, proved to be multidimensional and multifactorial with 81 factors and 71 items. The dimension task characteristics is composed of 6 factors: autonomy to plan tasks, autonomy in decision-making about working methods, variety of tasks (requirement of multiple tasks), meaning of the task (influence of work on other people's lives), task identity (work product) and feedback from work (information on performance). The second dimension, knowledge characteristics, covers 4 factors: work complexity (degree of complexity of tasks), information processing (demand for attention and data processing), problem solving / variety of skills, and specialization. The third dimension, social characteristics, is formed by 4 factors: social support, initiated and received task interdependence, interaction with people outside the organizational context, and feedback from others (co-workers, supervisor). The fourth dimension, characteristics of the context, is composed of 4 factors referring to: ergonomics, physical demands, working conditions, and use of equipment.

The studies found in a review by Santos and Sobrinho (2011) pointed out education professionals, especially teachers, as one of the high-risk professional categories for the development of BS. The studies found in the review also point to a high prevalence of the disease among primary and secondary school teachers, and reveal that BS is associated with the characteristics of the teaching work. Working conditions, such as work environment, work organization, materials and equipment, and pedagogical resources are important factors in the development of BS (Silva, Bolsoni-Silva, 
Rodrigues, \& Capellini, 2015). The high demands in the context of work, accompanied by the limited time to perform tasks, would generate emotional exhaustion in teachers (Maslach, Schaufeli, \& Leiter, 2001).

Regarding the organization of work, the lower the degree of autonomy, the greater the emotional exhaustion (Carlotto, 2004). Also according to the author, the role of the meaning of the task stands out, because as teachers perceive their work as insignificant, they tend to feel emotionally distant from their students, colleagues, and institution. The excess of work activities and the performance of tasks that go beyond the teaching function are directly related to emotional exhaustion and can be perceived by the reduction of physical and / or mental capacity (Escalona, Sánchez, \& Medina, 2007).

The systematic literature review on BS in health care professionals conducted by Sticca and Scotton (2019) identified a high prevalence of BS, and pointed to a high vulnerability of these professionals. Studies point out as risk variables: role conflicts (Rodriguez \& Carlotto, 2017), lack of recognition (Prestes, Beck, Magnago \& Silva, 2015; Zanatta \& Lucca, 2015), low control over the environment and task, little autonomy (Panunto \& Guirardello, 2013), and inadequate work and infrastructure conditions (Martins, Laport, Menezes, Medeiros, \& Ronzani, 2014). As protective factors, studies identify the social characteristics of work, such as harmonious interpersonal relationships, social support, organizational support (Andrade, Hoch, Vieira, \& Rodrigues, 2012; Barros et al., 2016; Campos, Angélico, Oliveira, \& Oliveira, 2015; Lorenz \& Guirardello, 2014), and the characteristics of the task, such as greater autonomy (Lorenz \& Guirardello, 2014; Rodriguez \& Carlotto, 2017).

Although in Brazil there are several studies that address BS in health care (Campos, Angélico, Oliveira, \& Oliveira, 2015; Rodriguez \& Carlotto, 2017;) and education professionals (Carlotto \& Câmara, 2017; Silva, Bolsoni-Silva, Rodrigues, \& Capellini, 2015), no study was found specifically addressing the relationship between work design and its relationship with BS. A systematic review of the literature, conducted by Dalcin and Carlotto (2017), whose objective was to identify the factors associated with BS in Brazilian teachers, did not identify any study on the characteristics of the job and BS. In another systematic review of the literature, developed by Sticca and Scotton (2019), seeking to identify factors associated with BS in health, education, and security professionals, no studies were found that aimed to analyze relationships between the characteristics of the profession and BS.

The identification of explanatory models of the BS specifically based on the perceptions of professionals about the design of the work they perform is important to support managers in the construction or modification of job design, aiming at the prevention of this occupational disease and its consequences for the health of the worker and his or her organization of work. It is also important to evaluate the specificities, considering health care and education professionals, since the public assisted marks important functional differences that impact the characteristics of work in these contexts. In this sense, the present study aims to identify the predictive power of the factors that compose the 3 dimensions of work design (task characteristics, knowledge characteristics, and social characteristics) on the 4 dimensions of BS (Enthusiasm towards the job, psychological exhaustion, Indolence, and Guilt) in Brazilian health care and education professionals.

\section{Method}

\section{Participants}

The non-probabilistic sample consisted of 300 education and health professionals, of which $188(62.67 \%)$ were from the education field and 112 $(37.33 \%)$ from health care. Regarding the position they held, $46.28 \%$ of education professionals and $36.61 \%$ of health professionals did not report their position. Among the 101 (53.72\%) education professionals who reported their positions, $75.25 \%$ were teachers and $24.75 \%$ held administrative or support / service positions); and of the $71(63.39 \%)$ health care professionals who reported their posts, $69.01 \%$ were senior specialist positions (psychologists, occupational therapists, etc.) and administrative positions, and 30.99\% were nurses and nurse technicians. Regarding the region of the country to which they belong, 132 (70.21\%) education professionals and $83(74.11 \%)$ health care professionals informed their region of origin, which are distributed as follows: $65 \%$ of education and $55 \%$ of health care workers were from the Southeast Region; $23 \%$ of education and $36 \%$ of health care professionals were from the South; $2 \%$ of education and $1 \%$ of health care professionals were from the Midwest Region; $1 \%$ of education and no health care professionals were from the North Region; and 9\% of education and 8\% of health care professionals were from the Northeast 
region of Brazil. Among education professionals, $51.60 \%$ were single or had no partner, and $48.40 \%$ were married or had a partner. Among health care professionals, $38.39 \%$ were single or did not have a partner and $61.61 \%$ were married or had a partner. As for sex, $71.28 \%$ of education professionals and $79.46 \%$ of health care professionals were women; and $28.72 \%$ of education professionals and $20.54 \%$ of health care professionals were men. Regarding the level of education, $90 \%$ of the education and health care professionals had at least higher education. The mean age of education professionals was 37.12 years $(\mathrm{SD}=10.11$; age range 21 - 68 years). The mean age of health professionals was 40.21 years $(S D=11.44$; are range 20 - 63 years).

As for the type of employment relationship, $38.30 \%$ of education professionals and $48.21 \%$ of health professionals were public employees and had stability in their careers; the others had labor contracts ruled by the Consolidation of Brazilian Labor Laws - CLT. As for the work shift, $68.09 \%$ of education professionals and $71.43 \%$ of health care professionals had a fixed shift, the others worked on a flexible schedule. In addition, $25 \%$ of education professionals and $29.46 \%$ of health care professionals had more than 1 professional activity, i.e., they worked in more than 1 institution or area of activity. The average length of experience for education professionals was 11.96 years $(\mathrm{SD}=9.06)$ and for health care professionals was 16.42 years $(S D=11.10)$. The average weekly workload of education professionals was 35.15 hours ( $\mathrm{SD}=12.39$ ), while that of health care professionals was 36.17 hours $(\mathrm{SD}=10.13)$.

\section{Instruments}

Questionnaire on Sociodemographic and Labor Data. Questionnaire covering sociodemographic (sex, age, education, marital status) and work-related information (length of professional experience, weekly workload, area (s) of work, fixed or flexible shift, type of employment relationship, having another professional activity).

Spanish Burnout Inventory (SBI) (Cuestionario para la evaluación del Sindrome de Quemarse por el Trabajo - CESQT) (Gil-Monte, 2005), version translated and adapted for Brazil by Gil-Monte, Carlotto and Câmara (2010). The CESQT-PE (Brazilian version) presents 20 items distributed in 4 subscales where 2 alphas are presented for each factor, the first of which comes from the study by Gil-Monte, Carlotto and Câmara (2010), and the second, from the analyses conducted in this study: Enthusiasm towards the job (5 items, alpha = $0.83 / 0.91$, ex: I see my work as a source of personal fulfillment), Psychological Exhaustion (4 items, alpha = 0.80 / 0.86, ex: I feel emotionally worn out), Indolence (6 items, alpha $=0.80 / 0.81$, ex: I don't like to meet some people at work), and Guilt (5 items, alpha $=0.82$ / 0. 81, ex: I regret some of my behaviors at work). The items are evaluated with a frequency scale of 5 points (ranging from 0 "never" to 4 "every day").

The Work Design Questionnaire (WDQ) (Morgeson \& Humphrey, 2006), short version, translated and applied to samples of Brazilian workers (BorgesAndrade, Peixoto, Queiroga, \& Pérez-Nébra, 2019). The original instrument consists of 77 items distributed in 4 dimensions with reliability rates in the original version ranging from 0.88 to 0.52 . In the present study, 63 items were used, referring to 3 dimensions, Task Characteristics - TC (24 items); Knowledge Characteristics - KC (20 items), and Social Characteristics - SC (19 items), all answered by a 5-point Likert scale in which 1 (one) corresponds to "totally disagree" and 5 (five) to "totally agree". Next we present 2 alphas for each factor, the first of which comes from the study by Borges-Andrade et al. (2019), and the second from the analyses conducted in this study. The first dimension includes the following 6 factors: work planning autonomy (3 items, alpha $=0.79 / 0.85$, e.g., my work allows me to decide when to do my tasks), decision and execution autonomy (6 items, alpha $=0.90 / 0.94$, e.g., my job allows me to make many decisions on my own), task variety (4 items, alpha $=0.92$ / 0.95, e.g. my work involves a wide variety of tasks), task significance (four items, alpha $=0.84 / 0.87$, e.g., it is likely that the results of my significantly affect other people's lives), task identity (4 items, alpha $=0.83 / 0.89$, e.g., my job allows me to complete what I started), feedback from job (3 items, alpha $=0.89 / 0.94$, e.g. my job provides feedback on my performance). The Knowledge Characteristics dimension is composed of 4 factors: work complexity (3 items, alpha $=0.86 / 0.89$, e.g. my work tasks are simple and uncomplicated), information processing (4 items, alpha $=0.83 / 0.89$, e.g., my job requires me to think hard), problem solving (6 items, alpha $=0.80 /$ 0.90 , e.g., my job requires the use of a variety of skills), and specialization ( 4 items, alpha $=0.86 / 0.87$, e.g., my work is highly specialized in relation to its purpose, tasks or activities). The Social Characteristics dimension is formed by 4 factors: social support (6 items, alpha $=0.83 / 0.86$, e.g., I have the opportunity to make friends at work), interdependence ( 5 items, alpha $=0.83$ 
/ 0.85, e.g., my colleagues' work depends directly on mine), interaction outside organization (4 items, alpha $=0.87 / 0.85$, e.g. my work requires me to devote a lot of time to people from outside the organization), feedback from others ( 3 items, alpha $=0.87 / 0.85$, e.g. I get feedback from others on my performance (such as my superiors or colleagues).

\section{Procedures}

The research was submitted and approved by the Research Ethics Committee of the University Vale do Rio dos Sinos - UNISINOS, under the approval number (CAAE: 78104317.1.0000.5344). Data collection was performed on the online platform Survey Monkey. The participants who accepted the invitation marked the "Free and Informed Consent Form" (FICF) with an " $\mathrm{X}$ ", which was found on the initial page of the instrument.

In order to recruit participants, an online invitation was sent to potential respondents from the researchers' contact network (Facebook, Linkedin) requesting that the questionnaire be completed and forwarded to their contact network. Data collection was conducted between January and August 2018.

\section{Data Analysis}

Quantitative analyses were performed in the SPSS software version 22.0, including exploratory analyses of the data file (data entry, presence of extreme cases, distribution of missing cases, frequency distribution of variables) and descriptive analyses (mean and standard deviation). The multiple linear regression analysis (stepwise method) was performed after assumption tests, aiming at the analysis of the relationships between the predictive variables, calculated by the means of the participants' responses to the 14 design factors at work, and the 4 criterion variables, defined as the mean responses to the 4 factors of $\mathrm{BS}$.

\section{Results}

Descriptive analyzes were performed for the BS and WDQ constructs for the 2 professional categories surveyed. Considering that the items of the BS instrument adopted in this study are associated with a frequency scale ranging from 1 (never) to 4 (every day), it is observed that the highest mean of the Burnout dimensions in both groups was that of Enthusiasm towards the job. In the dimensions of the work design instrument, in which the questions are associated with an agreement scale, ranging from 1 (strongly disagree) to 5 (strongly agree), it was verified that the highest means were Information processing and Problem solving in the education group, and Problem Solving and Task Significance in the group of health care participants.

\section{Relationship between Work Design and Burnout variables}

The relationship between WDQ factors and BS dimensions was verified by the analysis of multiple linear regression. Sociodemographic and labor variables were not included, as they were not significant in the explanatory power of the models. For each analysis performed, the Durbin-Watson index - DW was calculated, and the Kolmogorov-Smirnov test - KS (p $>0.05)$ found values indicative of an adequate adjustment of the models. The analysis of correlations between the dimensions of the BS and the factors of the WDQ of Education and Health care indicated the absence of multicollinearity, since the highest correlation value was 0.77 , found between the variables Information processing and Problem solving in education professionals.

Table 2 presents the results of multiple linear regression analysis for the criterion variable of $\mathrm{BS}$ Enthusiasm towards the job, in relation to the WDQ factors for education and health care professionals. We verified that, for the category of education professionals, 4 factors of the WDQ explained 31\% of the dimension Enthusiasm towards the job. In this sense, it seems that the higher the values attributed by the participants to the dimensions decision and execution autonomy, task variety, task significance (Characteristics of tasks), and feedback from others (Social characteristics), the greater the Enthusiasm towards the job.

For health care professionals, the greater the decision and execution autonomy (Characteristic of the task), the social support, and the feedback from others (Social characteristics of work), the greater the Enthusiasm towards the job. However, for this professional category, the increase in the job complexity (Characteristic of knowledge) decreases Enthusiasm towards the job. These factors together explain $36 \%$ of the variability of the participants' responses to this dimension.

Table 3 presents the results of the multiple linear regression analysis of the Psychological Exhaustion dimension of BS in relation to the WDQ factors for education and health care professionals. We verified that for education professionals, 4 factors of WDQ explain $25 \%$ of the dimension of Psychological Exhaustion. The analysis also showed that the lower the values 
Table 1.

Means and standard deviations of factors composing $B S$ and $W D Q$

\begin{tabular}{lllll}
\hline \multicolumn{1}{c}{ Variables } & \multicolumn{2}{c}{ Education } & \multicolumn{2}{c}{ Health } \\
\cline { 2 - 5 } & $M$ & $S D$ & & $S D$ \\
\hline BS Dimensions & & & & \\
Enthusiasm towards the job & 2.84 & 0.78 & 2.73 & 0.83 \\
Psychological Exhaustion & 2.14 & 0.87 & 2.14 & 0.89 \\
Indolence & 1.31 & 0.66 & 1.20 & 0.65 \\
Guilt & 1.35 & 0.68 & 1.18 & 0.61 \\
WDQ Dimensions & & & & \\
Work planning autonomy & 3.45 & 0.95 & 3.73 & 1.05 \\
Decision and execution autonomy & 3.41 & 1.01 & 3.58 & 0.98 \\
Task variety & 4.15 & 0.95 & 4.15 & 0.91 \\
Task significance & 4.15 & 0.88 & 4.40 & 0.70 \\
Task identity & 3.71 & 0.93 & 3.81 & 0.97 \\
Feedback from job & 3.44 & 1.05 & 3.56 & 1.08 \\
Job Complexity & 2.00 & 1.01 & 1.90 & 1.00 \\
Information processing & 4.38 & 0.86 & 4.41 & 0.68 \\
Problems solution & 4.21 & 0.87 & 4.24 & 0.72 \\
Specialization & 3.83 & 0.97 & 3.98 & 0.87 \\
Social support & 4.01 & 0.81 & 3.93 & 0.78 \\
Interdependence & 2.81 & 1.05 & 3.02 & 1.05 \\
Interaction outside the organization & 3.25 & 1.12 & 3.57 & 1.07 \\
Feedback from others & 2.78 & 1.09 & 2.77 & 1.23 \\
\hline
\end{tabular}

attributed by the participants to decision and execution autonomy, feedback from job (Characteristic of the task), and job complexity (Characteristic of knowledge), the greater the Psychological Exhaustion. However, the greater the problem solving (Characteristic of knowledge), the lower the Psychological Exhaustion.

For health care professionals, 4 factors of the WDQ explained $43 \%$ of the variability of the participants' responses to the Psychological Exhaustion dimension. It was verified that the lower the values attributed by the participants to decision and execution autonomy (Characteristic of the task), job complexity (Characteristic of knowledge), and social support (Social characteristic), the greater the Psychological Exhaustion. It was also verified that the greater the specialization (Characteristic of knowledge), the greater the Psychological Exhaustion.

Table 4 presents the results of the multiple linear regression analysis of the Indolence dimension of BS in relation to the WDQ factors for education and health care professionals. We verified that 3 factors of the WDQ explained $10 \%$ of the Indolence among education professionals. The lower the values attributed by the participants to task identification (Task characteristic) and social support (social characteristic), the greater the Indolence. We also verified that the greater the interdependence (social characteristic), the greater the Indolence.

Regarding health care professionals, 3 factors of the WDQ explained $35 \%$ of the variability of the Indolence dimension. It was verified that the lower the values attributed by the participants to decision and execution autonomy, task identity (Characteristics of the task), and the social support (Social characteristic), the greater the indolence among these professionals.

Table 5 presents the results of multiple linear regression analysis of the Guilt dimension of the BS in relation to the WDQ factors for education and health care professionals. It was verified that 2 factors of the WDQ explained only $4 \%$ of Guilt among education 
Table 2.

Multiple linear regression analysis of the dimension Enthusiasm towards the job and WDQ factors

\begin{tabular}{|c|c|c|c|c|c|}
\hline \multicolumn{6}{|c|}{ Education - Model 1} \\
\hline Predictive variables & Beta & Standard error & Standardized Beta & $t$ & $p$ \\
\hline Constant & 0.490 & 0.276 & & 1.774 & 0.078 \\
\hline Decision and execution autonomy & 0.253 & 0.050 & 0.330 & 5.103 & 0.000 \\
\hline Task variety & 0.129 & 0.058 & 0.159 & 2.214 & 0.028 \\
\hline Task significance & 0.125 & 0.061 & 0.142 & 2.053 & 0.042 \\
\hline Feedback from others & 0.156 & 0.045 & 0.219 & 3.487 & 0.001 \\
\hline \multicolumn{6}{|c|}{ Adjusted $\mathrm{R}^{2}=0.31 ; F(4.183)=21.662 ; p=0.0001 ; \mathrm{DW}=2.073$. Note. $p<0.05 ; \mathrm{KS}=0.327$} \\
\hline \multicolumn{6}{|c|}{ Health - Model 2} \\
\hline Predictive variables & Beta & Standard error & Standardized Beta & $t$ & $p$ \\
\hline Constant & 0.642 & 0.351 & & 1.830 & 0.070 \\
\hline Decision and execution autonomy & 0.278 & 0.072 & 0.327 & 3.886 & 0.000 \\
\hline Job complexity & -0.178 & 0.064 & -0.213 & -2.776 & 0.006 \\
\hline Social support & 0.241 & 0.098 & 0.226 & 2.464 & 0.015 \\
\hline Feedback from others & 0.173 & 0.058 & 0.255 & 3.004 & 0.003 \\
\hline \multicolumn{6}{|c|}{ Adjusted $\mathrm{R}^{2}=0.36 ; \mathrm{F}(4.107)=16.651 ; p=0.0001 ; \mathrm{DW}=2.027$. Note. $p<0.05 ; \mathrm{KS}=0.905$. } \\
\hline
\end{tabular}

professionals. The analysis also showed that the lower the task identity (Task characteristic), the greater the Guilt. Moreover, Guilt increased as interdependence (social characteristic) increased. Among health care professionals, 2 factors explained $21 \%$ of the Guilt dimension; it increased as decision and execution autonomy (Task characteristic) decreased and interdependence (Social characteristic) increased.

The magnitude of the effect of independent variables on the dimensions of $\mathrm{BS}$ in education professionals ranged from low $\left(\mathrm{R}^{2}=0.04\right)$ to high $\left(\mathrm{R}^{2}\right.$ $=0.31)$. In health professionals, the variation was medium $\left(\mathrm{R}^{2}=0.21\right)$ to high $\left(\mathrm{R}^{2}=0.43\right)$ according to the parameters recommended by Marôco (2007). In this sense, in the education group it is likely that only the relationships identified in the dimensions of Enthusiasm towards the job and Psychological Exhaustion are present in the target population. In the group of health care professionals, the probability is present in all dimensions, although with less magnitude in the dimension of Guilt.

\section{Discussion}

This study sought to identify the predictive power of work design variables (Task characteristics,
Knowledge characteristics, and Social characteristics) for the 4 dimensions of BS (Enthusiasm towards the job, Psychological Exhaustion, Indolence, and Guilt) in Brazilian health care and education professionals. The results identified explanatory models in which, for both professional categories, the WDQ factors are predictors of the 4 dimensions of BS, especially factors related to task characteristics and social characteristics. Knowledge characteristics appear as predictors only of psychological exhaustion in education; and in health care, they appear as predictors of psychological exhaustion and decreased Enthusiasm.

Decision and execution autonomy (task characteristics) appear as a predictor in 4 of the 8 eight models presented, a factor that decreases the dimensions of Psychological exhaustion, Indolence, and Guilt and increases Enthusiasm. A study conducted by Carlotto and Câmara (2017) with university professors also identified a positive association between autonomy and Enthusiasm. National studies point to autonomy as a protective factor of $\mathrm{BS}$ in health care professionals (Lorenz \& Guirardello, 2014; Panunto \& Guirardello, 2013; Rodriguez \& Carlotto, 2017).

Another recurring factor in work design is that of social support (component of the Social characteristic dimension), identified in 4 of the 8 models. The 
Table 3.

Multiple linear regression analysis of the Psychic Wear dimension and the WDQ factors

\begin{tabular}{|c|c|c|c|c|c|}
\hline \multicolumn{6}{|c|}{ Education - Model 3} \\
\hline Predictive variables & Beta & Standard error & Standardized Beta & $t$ & $p$ \\
\hline Constant & 2.726 & 0.363 & & 7.518 & 0.000 \\
\hline Decision and execution autonomy & -0.206 & 0.061 & -0.239 & -3.388 & 0.001 \\
\hline Feedback from job & -0.203 & 0.057 & -0.243 & -3.548 & 0.000 \\
\hline Job complexity & -0.187 & 0.059 & -0.216 & -3.158 & 0.002 \\
\hline Problem solution & 0.283 & 0.072 & 0.281 & 3.916 & 0.000 \\
\hline \multicolumn{6}{|c|}{ Adjusted $\mathrm{R}^{2}=0.25 ; \mathrm{F}(4.183)=16.591 ; p=0.0001 ; \mathrm{DW}=2.083$. Note. $p<0.05 . \mathrm{KS}=0.975$. } \\
\hline \multicolumn{6}{|c|}{ Health - Model 4} \\
\hline Predictive variables & Beta & Standard error & Standardized Beta & $t$ & $p$ \\
\hline Constant & 4.391 & 0.454 & & 9.675 & 0.000 \\
\hline Decision and execution autonomy & -0.256 & 0.074 & -0.280 & -3.460 & 0.001 \\
\hline Job complexity & -0.235 & 0.067 & -0.262 & -3.535 & 0.001 \\
\hline Specialization & 0.206 & 0.077 & 0.200 & 2.688 & 0.008 \\
\hline Social support & -0.434 & 0.091 & -0.379 & -4.789 & 0.000 \\
\hline \multicolumn{6}{|c|}{ Adjusted $\mathrm{R}^{2}=0.43 ; \mathrm{F}(4.107)=21.952 ; p=0.0001 ; \mathrm{DW}=1.890$. Note. $p<0.05 . \mathrm{KS}=0.775$} \\
\hline
\end{tabular}

Table 4.

Multiple linear regression analysis of the dimension Indolence and the WDQ factors

\begin{tabular}{|c|c|c|c|c|c|}
\hline \multicolumn{6}{|c|}{ Education - Model 5} \\
\hline Predictive variables & Beta & Standard error & Standardized Beta & $t$ & $p$ \\
\hline Constant & 2.131 & 0.268 & & 7.940 & 0.000 \\
\hline Task identity & -0.126 & 0.052 & -0.178 & -2.420 & 0.016 \\
\hline Social Support & -0.168 & 0.061 & -0.208 & -2.760 & 0.006 \\
\hline Interdependence & 0.115 & 0.045 & 0.185 & 2.588 & 0.010 \\
\hline \multicolumn{6}{|c|}{ Adjusted $\mathrm{R}^{2}=0.10 ; \mathrm{F}(3.184)=7.951 ; p=0.0001 ; \mathrm{DW}=1.836$. Note. $p<0.05 . \mathrm{KS}=0.832$} \\
\hline \multicolumn{6}{|c|}{ Health - Model 6} \\
\hline Predictive variables & Beta & Standard error & Standardized Beta & $t$ & $p$ \\
\hline Constant & 3.215 & 0.281 & & 11.457 & 0.000 \\
\hline Decision and execution autonomy & -0.258 & 0.057 & -0.390 & -4.508 & 0.000 \\
\hline Task identity & -0.125 & 0.058 & -0.187 & -2.167 & 0.032 \\
\hline Social support & -0.156 & 0.074 & -0.188 & -2.119 & 0.036 \\
\hline Adjusted $\mathrm{R}^{2}=0.35 ; \mathrm{F}(3.108)=20.824 ; p=$ & 58. Note. $p$ & $0.05 . \mathrm{KS}=0.601$ & & & \\
\hline
\end{tabular}

data corroborate previous studies in which the lack of social support (Marqués-Pinto, Lima, \& Lopes da Silva, 2005) appears as one of the triggering factors of BS in education professionals. The support of colleagues and supervisors to face difficulties at work can help minimize mental suffering and increase 
Table 5.

Multiple linear regression analysis of the Guilt dimension and WDQ factors

\begin{tabular}{|c|c|c|c|c|c|}
\hline \multicolumn{6}{|c|}{ Education - Model 7} \\
\hline Predictive variables & Beta & Standard error & Standardized Beta & $t$ & $p$ \\
\hline Constant & 1.452 & 0.237 & & 6.113 & 0.000 \\
\hline Task identity & -0.110 & 0.053 & -0.151 & -2.100 & 0.037 \\
\hline Interdependence & 0.108 & 0.047 & 0.167 & 2.328 & 0.021 \\
\hline \multicolumn{6}{|c|}{ Adjusted $R^{2}=0.04 ; F(2.185)=4.808 ; p=0.009 ; \mathrm{DW}=1.833$. Note. $p<0.05 . \mathrm{KS}=0.938$. } \\
\hline \multicolumn{6}{|c|}{ Health - Model 8} \\
\hline Predictive variables & Beta & Standard error & Standardized Beta & $t$ & $p$ \\
\hline Constant & 1.196 & 0.273 & & 4.375 & 0.000 \\
\hline Decision and execution autonomy & -0.168 & 0.054 & -0.268 & -3.109 & 0.002 \\
\hline Interdependence & 0.195 & 0.050 & 0.335 & 3.884 & 0.000 \\
\hline \multicolumn{6}{|c|}{ Adjusted $\mathrm{R}^{2}=0.21 ; \mathrm{F}(2.109)=15.362 ; p=0.0001 ; \mathrm{DW}=2.328$. Note. $p<0.05 . \mathrm{KS}=0.987$. } \\
\hline
\end{tabular}

self-esteem, facilitating the feeling that one's goals are being achieved.

The analysis of the predictors of the dimension Psychological Exhaustion revealed that in education professionals the greater the decision and execution autonomy, the feedback from job, and the job complexity, the lower the Psychological Exhaustion, and in health professionals, the greater the decision and execution autonomy, the job complexity, and the social support, the lower the Psychological Exhaustion. Previous studies conducted with teachers have also identified that Psychological Exhaustion can decrease with greater autonomy, positive feedback, and job satisfaction (Carlotto \& Dalcin, 2017). As for health care professionals, social support and autonomy had already been identified as protective factors for BS in the studies by Rodriguez and Carlotto (2017) and by Barros et al. (2016).

Regarding Indolence, task identity and social support are predictors in health care professionals, and the values attributed by participants to decision and execution autonomy, task identity, and social support are predictors in education professionals. Previous studies point to the variable interpersonal conflicts in the work context (Carlotto \& Câmara, 2017; Malmann, Palazzo, Carlotto, \& Aerts, 2009) as a predictor of indolence in education professionals.

As for the Guilt dimension in education professionals, the results indicate that the lower the task identity and the greater the interdependence, the lower the feelings of guilt, while for health professionals, the lower the decision and execution autonomy and the greater the interdependence of tasks, the greater the guilt. It is likely that in the case of education, professionals who perform incomplete tasks (task characteristics), without a clearly identifiable and interdependent beginning and end (social characteristics) develop feelings of guilt because they are not able to properly coordinate their efforts with those of others and thus satisfactorily achieve work goals. In the case of health professionals, it is possible that the interdependence of the task, typical of this context, by requiring coordination of efforts between team members and shared decision-making with other professionals, is characterized by a low autonomy in task performance and decision-making, increasing the occurrence of feelings of guilt, probably due to the loss of individual control over the achievement of the work objectives, despite the substantive individual and collective efforts, necessary to perform the tasks.

One of the strengths of the research concerns the use of a consistent theoretical model and instruments adapted to the Brazilian context with adequate levels of reliability. The sample size proved to be sufficient to reveal good levels of power effect in most explanatory models.

However, the study has some limitations that should be considered when reading its results. The first is due to the use of self-report measures that can generate a bias related to social desirability, such as the fact that 
health care and education professionals do not mention issues related to the dimension of Indolence, as it may be difficult to admit a distant and impersonal behavior towards students and patients. The second refers to the cross-sectional design that evaluates the characteristics of the job as a static work characteristic, as this is a construct that presents variability due to socio-political influences (Parker, Morgeson, \& Gary, 2017).

The third limitation concerns the 'healthy worker effect', which can occur in cross-sectional studies in occupational epidemiology that often exclude the possible patient (McMichael, 1976). In the case of Burnout, respondents, due to illness, are already away from work and did not have access to the research invitation. In relation to future studies, we suggest that longitudinal studies be conducted to assess the behavior and stability of predictive models and new studies that investigate work design in depth with samples of different professional categories, positions, and functions that make up the teams, units, and institutions in the educational and health care areas in Brazil.

The results obtained reveal that variables related to work design are predictors of BS. Regarding the implications for the practice, actions aimed at redesigning jobs and activities of these professional categories are suggested, aiming to ensure greater autonomy in decision-making and task performance, as well as greater coordination of efforts in jobs that require high interdependence, because there is evidence that social interactions can bring both benefits (support) and costs (substantive energy expenditure). Task interdependence requires additional efforts by the individual to constantly monitor, manage, and interrelate inputs and work products, which can cause exhaustion (Windeler, Chudoba, \& Sundrup, 2017). As a result, we recommend the analysis of the influence of the degree of interdependence of work on the dimensions of BS, including research on the effect of the quantity and quality of interactions required by the activities of these professionals. Likewise, actions aimed at encouraging social support from supervisors and peers are recommended, as a protective measure of BS.

\section{References}

Andrade, T. de,, Hoch, R. E. E., Vieira, K. M., \& Rodrigues, C. M. C. (2012). Síndrome de Burnout e Suporte Social no Trabalho: a percepção dos profissionais de enfermagem de hospitais públicos e privados. Organizaçoes \& Sociedade, 19(61), 231251. doi: 10.1590/S1984-92302012000200004
Bakker, A. B., \& Costa, P. L. (2014). Chronic job burnout and daily functioning: a theoretical analysis. Burnout Research, 1(3), 112-119. doi:10.1016/j. burn.2014.04.003

Barros, M. M. D. S., Almeida, S. P. D., Barreto, A. L. P., Faro, S. R. S., Araújo, M. R. M. D., \& Faro, A. (2016). Síndrome de Burnout em médicos intensivistas: estudo em UTIs de Sergipe. Temas em Psicologia, 24(1), 377-389. doi: 10.9788/TP2016.1-26

Borges-Andrade, J. E., Peixoto, A. L. A., Queiroga, F., \& Pérez-Nebra, A. R. (2019). Adaptação do Questionário de Desenho do Trabalho para o Brasil. Revista Psicologia Organizações e Trabalho, 19(3), 720731. doi: 10.17652/rpot/2019.3.16837

Borritz, M., Bultmann, U., Rugulies, R., Christensen, K. B., Villadsen, E., \& Kristensen, T. S. (2005). Psychosocial work characteristics as predictors for burnout: Findings from 3-year follow up of the PUMA Study. Journal of Occupational and Environmental Medicine, 47, 1015-1025. doi: 10.1097/01. jom.0000175155.50789.98

Campos, I. C. M., Angélico, A. P., Oliveira, M. S., \& Oliveira, D. C. R. (2015). Sociodemographic and occupational factors associated with burnout syndrome among nursing professionals. Psicologia: Reflexão e Crítica, 28(4), 764-771. doi:10.1590/1678-7153.201528414

Carlotto, M. S. (2004). Síndrome de burnout e caraterísticas de cargo em professores universitários. Revista Psicologia Organizações e Trabalho, 4(2), 145162. Recuperado de: http://pepsic.bvsalud.org/ pdf/rpot/v4n2/v4n2a07.pdf

Carlotto, M. S. (2011). Fatores de risco da síndrome de burnout em técnicos de enfermagem. Revista da SBPH, 14(2), 07-26. Recuperado de: http://pepsic.bvsalud.org/scielo.php?script=sci_arttext\&pid =S1516-08582011000200003

Carlotto, M. S., \& Câmara, S. G. (2017). Riscos psicossociais associados à síndrome de burnout em professores universitários. Avances en Psicología Latinoamericana, 35(3), 447-457. doi: 10.12804/10.12804/revistas.urosario.edu.co/ apl/a.4036

Chirico, F. (2017). Is it time to consider burnout syndrome an occupational disease? Letters to the Editor. The British Journal of Psychiatry, 190(1), 81. doi: 10.1192/bjp.190.1.81a 
Dalcin, L. \& Carlotto, M. S. (2017). Síndrome de burnout em professores no Brasil: considerações para uma agenda de pesquisa. Psicologia em Revista, 23(2), 745771.doi:10.5752/P.1678-9563.2017v23n2p745-770

Escalona, E., Sánchez, T., \& Medina, M. G. (2007). Estrategias participativas en la identificación de la carga de trabajo y problemas de salud en docentes de escuelas primarias. Salud de los Trabajadores, 15(1), 17-35. Recuperado de: https://dialnet.unirioja.es/ descarga/articulo/2391319.pdf

Esteves-Ferreira, A. A., Santos, D. E \& Rigolon, R. G. (2014). Avaliação comparativa dos sintomas da síndrome de Burnout em professores de escolas públicas e privadas. Revista Brasileira de Educação, 19(59), 987-1002. Recuperado de: https:/ / www.scielo.br/scielo.php?pid=S141324782014000900009\&script $=$ sci_abstract\&tlng $=$ pt

Feliciano, K. V. D. O., Kovacs, M. H., \& Sarinho, S. W. (2011). Burnout entre médicos da Saúde da Família: os desafios da transformação do trabalho. Revista Ciência \&o saúde Coletiva, 16(8), 3373-3382. Recuperado de: https://www.scielo.br/pdf/csc/ v16n8/a04v16n8.pdf

Fernet, C., Austin, S. Trépanier, S-G., \& Dussault, M. (2013). How do job characteristics contribute to burnout? Exploring the distinct mediating roles of perceived autonomy, competence, and relatedness. European Journal of Work and Organizational Psychology, 22(2), 123-137. doi: 10.1080/1359432X.2011.632161

Galindo, R. H., Feliciano, K. V. D. O., Lima, R. A. D. S., \& Souza, A. I. D. (2012). Burnout syndrome among general hospital nurses in Recife. Revista da Escola de Enfermagem da USP, 46(2), 420-427. Recuperado de: https://www.scielo.br/scielo.php?script=sci_artte xt\&pid=S0080-62342012000200021

Gil-Monte, P. R (2005). El síndrome de quemarse por el trabajo (burnout). Una enfermidad laboral en la sociedad del bienestar. Madrid: Pirâmide.

Gil-Monte, P. R. (2011). CESQT - Cuestionario para la evaluación del sindrome de quemarse por el trabajo: manual. Madrid: TEA.

Gil-Monte, P. R., Carlotto, M. S., \& Câmara, S. G. (2010). Validation of the Brazilian version of the "Spanish Burnout Inventory" in teachers. Revista de Saúde Pública, 44(1), 140-147. doi:10.1590/ S0034-89102010000100015
Jindal, A., Garg, P., \& Rastogi, R. (2014). Decoding impact of job design on employee burnout. Apeejay Business Review, 13, 1 \& 2, 28-37. Recuperado de: https://www.apeejay.edu/asm/doc/ABR_December_2014.pdf\#page=28.

Koga, G. K. C., Melanda, F. N., Santos, H. G., Sant`Anna, F. L., González, A. D., Mesas, A. E., \& Andrade, S. M. (2015). Fatores associados a piores níveis de Burnout em professores da educação básica. Cadernos Saúde Coletiva, 23(3), 268-275. Recuperado de: https://www.scielo.br/pdf/cadsc/v23n3/1414-462X-cadsc-23-3-268.pdf

Lima, R. A. D. S., Souza, A. I. D., Galindo, R. H., \& Feliciano, K. V. D. O. (2013). Vulnerability to burnout among physicians at a public hospital in Recife. Ciência \& Saúde Coletiva, 18(4), 1051-1058. Recuperado de: https://www.scielo.br/pdf/csc/ v18n4/18.pdf

Lorenz, V. R., \& Guirardello, E. D. B. (2014). The environment of professional practice and Burnout in nurses in primary healthcare. Revista Latino-americana de Enfermagem, 22(6), 926-933. doi: 10.1590/0104-1169.0011.2497

Mallmann, C. S., Palazzo, L. S., Carlotto, M. S., \& Aerts, D. R. G. de C. (2009). Fatores associados à síndrome de burnout em funcionários públicos municipais. Psicologia: Teoria e Prática, 11(2), 69-82. Recuperado de: http://pepsic.bvsalud.org/scielo.php?script=sci_arttext\&pid $=$ S1516-36872009000200006

Marôco, J. (2007). Análise Estatística: Com Utilização do SPSS ( $3^{\mathrm{a}}$ ed.). Lisboa: Edições Sílabo.

Marqués-Pinto, A., Lima, M. L., \& Lopes da Silva, A. (2005). Fuentes de estrés, Burnout y estrategias de coping en profesores portugueses. Revista de Psicología del Trabajo y de las Organizaciones, 21, 125-143. Recuperado de: http://www.redalyc.org/articulo. oa?id $=231317039008$

Martins, L. F., Laport, T. J., Menezes, V. D. P., Medeiros, P. B., \& Ronzani, T. M. (2014). Burnout syndrome in primary health care professionals. Ciencia \& Saude Coletiva, 19(12), 4739-4750. doi: 10.1590/1413-812320141912.03202013

Maslach, C. (2017). Finding solutions to the problem of burnout. Consulting Psychology Journal: Practice and Research, 69(2), 143-152. doi: 10.1037/cpb0000090 
Maslach, C., \& Leiter, M. P. (2016a). New insights into burnout and health care: strategies for improving civility and alleviating burnout. Medical Teacher, 39(2), 160-163. doi: 10.1080/0142159X.2016.1248918

Maslach, C., \& Leiter, M. P. (2016b). Understanding the burnout experience: recent research and its implications for psychiatry. World Psychiatry, 15(2), 103-111. doi:10.1002/wps.20311

Maslach, C., Schaufeli, W. B., Leiter, M. P. (2001). Job burnout. Annual Review Psychology, 52(1), 397-422. doi: 10.1146/annurev.psych.52.1.397

McMichael, AJ. (1976). Standardized mortality ratio and the healthy worker effect scratching beneath the surface. Journal of Occupational Medicine, 81, 165168. Recuperado de: https://journals.lww.com/ joem/Citation/1976/03000/Standardized_Mortality_Ratios_and_the_Healthy.9.aspx

Morgeson, F. P., \& Humphrey, S. E. (2006). The Work Design Questionnaire (WDQ): Developing and validating a comprehensive measure for assessing job design and the nature of work. Journal of Applied Psychology, 91(6), 1321-1339. doi: 10.1037/0021-9010.91.6.1321

Morgeson, F. P., \& Humphrey, S. E. (2008). Job and team design: Toward a more integrative conceptualization of work design. In J. Martocchio (Ed.), Research in personnel and human resource management (Vol. 27, pp. 39-91). London, UK: Emerald Group Publishing Limited.

Novais, R. N. D., Rocha, L., Eloi, R. J., Santos, L. M. D., Ribeiro, M. V. M. R., Ramos, F. W. D. S., Lima, F. J. C., Souza-Rodrigues, S. F. \& Barbosa, F. T. (2016). Burnout Syndrome prevalence of on-call surgeons in a trauma reference hospital and its correlation with weekly workload: cross-sectional study. Revista do Colégio Brasileiro de Cirurgiões, 43(5), 314-319. Recuperado de: https://www.scielo.br/scielo.php?pid=S010069912016000500314\&script=sci_arttext

Panunto, M. R., \& de Brito Guirardello, E. (2013). Ambiente da prática profissional e exaustão emocional entre enfermeiros de terapia intensiva. Revista Latino-Americana de Enfermagem, 21(3), 765-772. doi: 10.1590/S0104-11692013000300016

Parker, S., Morgeson, F., \& Gary, G. (2017). One hundred years of work design research: looking back and looking forward. Journal of Applied Psychology, 102(3), 403-420. doi: 10.1037/ap10000106

Pisanti, R., van der Doef, M., Maes, S., Meier, L. L., Lazzari, D., \& Violani, C. (2016). How changes in psychosocial job characteristics impact burnout in nurses: A longitudinal analysis. Frontiers in Psychology, 7, 1082. doi: 10.3389/fpsyg.2016.01082

Prestes, F. C., Beck, C. L. C., Magnago, T. S. B. D. S., \& Silva, R. M. D. (2015). Pleasure-suffering indicators of nursing work in a hemodialysis nursing service. Revista da Escola de Enfermagem da USP, 49(3), 465472. doi: 10.1590/S0080-623420150000300015

Queirós, C., Carlotto, M. S., Kaiseler, M., Dias. S., \& Pereira, A. M. (2013). Predictors of Burnout among nurses: An interactionist approach. Psicothema, 25(3), 330-335. doi: 10.7334/psicothema2012.246

Rodriguez, S. Y. S., \& Carlotto, M. S. (2017). Predictors of burnout syndrome in psychologists. Estudos de Psicologia (Campinas), 34(1), 141-150. doi:10.1590/1982-02752017000100014

Santos, A. A., \& Sobrinho, C. L. N. (2011). Revisão sistemática da prevalência de burnout em professores do ensino fundamental e médio. Revista Baiana de Saúde Pública, 35(2), 299-319. Recuperado de: http://files.bvs.br/upload/S/0100-0233/2011/ v35n2/a2444.pdf

Silva, N. R., Bolsoni-Silva, A. T., Rodrigues, O. M. P. R., \& Capellini, V. L. M. F. (2015). O trabalho do professor, indicadores de burnout, práticas educativas e comportamento dos alunos: correlação e predição. Revista Brasileira de Educação Especial, 21(3), 363-376. doi: 10.1590/s1413-65382115000300004

Sticca, M. G., \& Scotton, I. (2019). A síndrome de Burnout na perspectiva da psicologia organizacional e do trabalho. In A. V. Carvalho (Ed.), Terapia Cognitivo Comportamental na Sindrome de Burnout: contextualização e intervenções (pp.87-121). Sinopsys Ltda.

Tironi, M. O. S., Teles, J. M. M., Barros, D. D. S., Vieira, D. F. V. B., Silva Filho, C. M. D., Martins Júnior, D. F., Matos, M. A., \& Nascimento Sobrinho, C. L. (2016). Prevalência de síndrome de burnout em médicos intensivistas de cinco capitais brasileiras. RevistaBrasileira de Terapia Intensiva, 28(3), 270-277. Recuperado de: https://www.scielo.br/scielo.php?pid=S0103507X2016000300270\&script $=$ sci_abstract\&tlng=pt 
Windeler, J. B., Chudoba, K. M., \& Sundrup, R. Z. (2017). Getting away from them all: Managing exhaustion from social interaction with telework. Journal of Organizational. Behavior, 38, 977-995. doi: 10.1002/job.2176

Zanatta, A. B., \& Lucca, S. R. D. (2015). Prevalence of Burnout syndrome in health professionals of an onco-hematological pediatric hospital. Revista da Escola de Enfermagem da USP, $49(2)$, 253-258. doi: 10.1590/S0080-623420150000200010

Recebido em: 09/07/2019

Reformulado em: 10/04/2020

Aprovado em: 21/05/2020

Sobre os autores:

Mary Sandra Carlotto is a psychologist, $\mathrm{PhD}$ in Social Psychology, professor at the Graduate Program in Psychology of the Universidade do Vale do Rio dos Sinos. She is a productivity research fellow at CNPq.

ORCID: http://orcid.org/0000-0003-2336-5224

E-mail:mscarlotto@unisinos.br

Gardênia da Silva Abbad is a psychologist, Master and PhD in Psychology, professor at the Graduate and Undergraduate Levels in the Department of Social-Organizational and Work Psychology of the Universidade de Brasília and in the Graduate Program in Administration of the Universidade de Brasilia. Productivity research fellow at CNPq. ORCID: https://orcid.org/0000-0003-0807-3549

E-mail: gardenia.abbad@gmail.com

Marina Greghi Sticca is a psychologist and administrator, professor at the Department of Psychology and at the Graduate Program in Psychology of the Faculty of Philosophy, Sciences and Languages at the Universidade de São Paulo.

ORCID: https://orcid.org/0000-0002-0838-0189

E-mail: marinagreghi@ffclrp.usp.br

Maria Nivalda de Carvalho-Freitas is a psychologist, PhD in Business Administration, professor at the Department of Psychology and at the Graduate Program in Psychology of the Universidade Federal de São João del-Rei. Productivity research fellow at CNPq.

ORCID: https://orcid.org/0000-0001-7071-7179

E-mail: nivalda@ufsj.edu.br

Marcos Santos de Oliveira is a statistician, Master and $\mathrm{PhD}$ in Statistics, professor at the Department of Mathematics and Statistics and at the Graduate Program in Psychology of the Universidade Federal de São João del-Rei.

ORCID: https://orcid.org/0000-0003-4395-4640

E-mail:mso@ufsj.edu.br

Contato com os autores:

mscarlotto@unisinos.br

marinagreghi@ffclrp.usp.br

Psico-USF, Bragança Paulista, v. 26, n. 2, p. 291-303, abr./jun. 2021 